This is a pre-copyedited, author-produced PDF of an article accepted for publication in Parliamentary affairs following peer review. The version of record, Parliamentary Affairs, Volume 70, Issue 2, 1 April 2017, Pages 191-206, is available online at: https://doi.org/10.1093/pa/gsw031

\title{
Speaking for Parliament
}

\section{Philip Norton*}

School of Law and Politics, University of Hull, Hull Hu6 7RX

*Correspondence: p.norton@hull.ac.uk

The UK Parliament in recent decades has seen significant structural and behavioural changes that have rendered it more effective in carrying out its core functions than at any time in modern political history. These changes have not impacted greatly on public perceptions of Parliament and its members.

Parliament and parliamentarians have been the source of declining satisfaction. The public have been more influenced by their perceptions of parliamentarians' behaviour than a results-based performance. Parliamentarians have not recognised the source of the dissatisfaction and have no clear institutional mechanism for responding to it. There is no one authoritative figure who can speak for Parliament. To combat public perceptions requires a proactive and collective response on the part of members of both Houses.

Keywords: Parliament, House of Commons, House of Lords, MPs, peers, crisis management, public dissatisfaction, institutional change

\section{Introduction}

The thesis of this article is straightforward. For the UK Parliament, these are the best of times, these are the worst of times. They are the best of times in its relationship to the executive. They are the worst of times, certainly the worst of times in contemporary history, in its relationship to the public. 
Students of politics have tended to focus on Parliament in terms of its relationship to the executive and not on its relationship to the people. In its relationship to the executive, there is good news to report. Both Houses have become more confident and more able in fulfilling their core functions of scrutiny and calling government to account. The extent to which this has occurred is not fully recognised. Both Houses have undergone substantial change, making Parliament as effective as it has ever been since the passage of the Second Reform Act in 1867. That is not to say that it has reached an ideal state - there is more than can, and should, be done - but it is in a better state than it has been for more than 150 years.

The situation is different in its relationship to the people. Enoch Powell observed that the House of Commons is the body through which the people, through their representatives, speak to the government, and the body through which government speaks to the people. That core, pivotal - and exclusive - role, for no other body can fulfil it, becomes even more important as decisions are seen as being taken further and further away from the people. The more that happens the more important it is that people have a voice through their parliament.

Yet what we are witnessing is a situation where both Houses are subject to negative coverage and public dissatisfaction. Resources are devoted to educating people about the institution, but not necessarily to defending it from scandal and a constant barrage of criticism. There has tended to be what may be characterised as a 'tin hats' mentality, sheltering in the bunker and trying to escape the barrage of media missiles. Parliament lacks the confidence and the resources to mount an effective counteroffensive. 


\section{The Best of Times}

Let me take the best of times, the relationship to the executive in the United Kingdom.

For the century after 1867, the House of Commons was essentially a chamberoriented, predictable body, accepting what was told to it by government. It is now a more committee-oriented, questioning, less predictable body, no longer willing to accept that government has a monopoly as an information supplier. It has also acquired a power that would have been unthinkable fifty years ago. The House of Lords has been transformed, reinventing itself as a chamber of scrutiny, especially legislative scrutiny, complementing the work of the House of Commons. Both Houses are now among the busiest legislative chambers in the world.

MPs are far less biddable than they were. We have seen behavioural and institutional change on a remarkable scale. As Philip Cowley has variously observed, we still hear the occasional commentator bemoan the end of the era of the independent member. The reality is that it has been the other way round. We have moved from what Sam Beer termed ‘the Prussian discipline’ of the 1950s and 1960s (Beer 1969, pp. 350-1) to an era when the whips cannot always guarantee the outcome of a vote (Norton 1975, 1978, 1980, 1985, 2012, Cowley 2002, 2005, 2015, Cowley and Norton 1999, Cowley and Stuart 2012, 2014). We retain high levels of cohesion, but nothing on the scale of fifty and sixty years ago. 
The government not only does not control voting outcomes in the way that it once did, but also no longer exerts an iron grip on the parliamentary agenda. The House of Commons used to be an outlier among national legislative chambers in terms of the control exerted by government over the timetable (Saalfeld, 2000, p. 28). Recent years have seen that grip significantly loosened. The government now is only one actor, albeit the most important, in determining the business of the House. The capacity to determine what is debated is shared with opposition parties, who select the topics on 20 Opposition Days. There is the independent capacity of Members to raise issues through ballot or the Speaker and through the greater willingness of the Speaker to grant urgent questions. We have had the creation of debates in Westminster Hall (Norton 2013, pp. 31-32, 115-17), in essence a parallel chamber based on Australian experience, creating additional time for Members to raise issues of concern to them and elicit a government response.

It is a capacity shared with committees of the House. The seepage of agenda power to committees is relatively new, starting with the Liaison Committee, comprising the chairs of select committees, being empowered to choose the topics on three Estimates Days. We have had the establishment of the Backbench Business Committee (Norton 2013, pp. 32, 114), with the power to determine business on 35 days (27 of them on the floor of the House). It selects topics proposed by Members, a good number of which the government may well have preferred not to be debated, such as prisoner voting rights, the war in Afghanistan, and a referendum on EU membership. The most recent addition is a Petitions Committee, which considers public petitions and can refer topics to other committees as well as undertake its own inquiries and 
schedule debates in Westminster Hall. By the summer of 2016, over 20,000 petitions were online.

The government no longer enjoys a virtual monopoly on the supply of information to the House. The House has enhanced its scrutiny role through the use of investigative select committees. The creation of a series of departmental select committees in 1979 was the most important reform of the latter half of the $20^{\text {th }}$ Century, possibly of the Century (Drewry 1989, Hawes 1993, Jogerst 1993, Natzler and Hutton 2005, Hindmoor, Larkin and Kennon 2009). It provided a degree of specialisation previously lacking and enabled the House through committees to scrutinise the work of departments. Concomitantly, the committees provide the House with alternative sources of advice to the government. They are prolific in delivering reports, reports that are reasoned, evidence-based and usually the product of unanimity on the part of the cross-party, and government majority, membership.

The status and arguably the impact of the committees have been reinforced by the Wright reforms of 2010 (Russell 2011, pp. 612-33), implementing the recommendations of the Select Committee on Reform of the House of Commons, chaired by Tony Wright. These give the chairs of the committees an enhanced profile and independence through being elected by the House and, at the same time, removing a key patronage tool of the whips. The chairs and members of committees have now to attract the support of fellow Members and not the favour of the whips.

The impact of MPs in the legislative process has largely been discounted. Few backbench or Opposition amendments to bills are accepted and the committee stage of 
a bill is seen especially as an exercise in going through the motions. Yet here again, the reality does not quite match the perception. The introduction of public bill committees in 2006 enhanced the capacity of MPs to be informed about a measure, further diluting the government's hold on information supplied to Members. As Louise Thompson has shown, the committees have a greater impact than is apparent from the number of non-government amendments accepted (Thompson 2016, pp. 3648; see also Thompson 2015). This encompasses achieving changes to regulations and guidance and changes made by government after committee stage which can be attributed to the committee itself. As she writes:

If we quantify the impact of committee stage... on the basis of the number of amendments directly influenced by committee stage, we see the impact of bill committees much more prominently. Instead of being responsible for only 88 changes across the $2000-2010$ period, it can be seen that in reality committee stage has prompted at least 1,900 changes to government legislation. (Thompson 2016, pp. 43-4).

As she notes, this is confined to the House of Commons. If extended the Lords, the figures would be even higher.

Perhaps the most overlooked in terms of its sheer constitutional significance, is the extent to which the government is now constrained in the exercise of prerogative powers. The most significant change has been the development of the practice, amounting now in the view of some to a convention, that before the executive commits British forces to action abroad the consent of the House of Commons must 
be given (Norton 2015, pp. 177-9). The precedent was set in 2003, when Foreign Secretary Jack Straw, assisted by former Foreign Secretary, Robin Cook, persuaded the Prime Minister, Tony Blair, that the consent of the House of Commons should be sought before committing British forces to war in Iraq (Straw, 2012, p. 375). It had its most notable public manifestation on 29 August 2013 when the House of Commons defeated, by 285 votes to 272, a government motion supporting military intervention in Syria (HC Deb., 29 Aug. 2013, cols. 1552-5). It was the most important defeat of the government on a matter of military involvement since the mid$19^{\text {th }}$ Century, in other words since the emergence of party government in the United Kingdom.

The House has also formally acquired, under the Constitutional Reform and Governance Act 2010, a treaty-making power, or the power to resolve that a treaty not be ratified. (Part 2 of the Act provides that a treaty shall be ratified if within 21 sitting days neither House has resolved that the treaty shall not be ratified.) This may acquire greater significance in the light of negotiations for the UK's withdrawal from the European Union. Then there is the effect of the Fixed-term Parliaments Act 2011. This not only removes the power of the Prime Minister to recommend dissolution for the purposes of an opportunistic election, it also rids the Prime Minister of the power to make a motion a vote of confidence and threaten a general election if the motion is not passed. A Prime Minister can no longer say, as Edward Heath did on Second Reading of the European Communities Bill in 1972, 'if this House will not agree to the Second Reading of the Bill.... my colleagues and I are unanimous that in these circumstances this Parliament cannot sensibly continue' (HC Deb. 17 Feb. 1972, col. 752). The effect of the 2011 Act is to embolden recalcitrant government 
backbenchers, who know now that they can vote against their own side on a major issue knowing that a government defeat will not trigger an election (Norton 2016a, pp. 3-18).

We then come to the House of Lords. It too has undergone a transformation in membership, behaviour and structures. The combination of the Life Peerages Act 1958, allowing the creation of peerages to be held only for the lifetime of the holder, and the House of Lords Act 1999, removing most hereditary peers, converted the membership from one of aristocracy to one largely based on meritocracy. Members are appointed primarily on the basis of their experience or expertise. The 1999 Act resulted also in no one party having a majority in the House. The House has reinvented itself as a chamber of legislative scrutiny, meeting frequently and with an attendance level that creates a major burden on the resources of the House.

It is more independent than the Commons in terms of its willingness to defeat the government, though not necessarily a House of more independent members. Peers are more loyal to the party whip than are MPs (Norton 2003, pp. 57-72). However, the government is vulnerable to defeat as a result of opposition parties combining against it or, especially in the period of coalition government 2010-15, crossbench (that is, independent) peers voting in large numbers with the opposition. Because the government does not have an overall majority in the House, it has to take it seriously in order to get its measures through. That and the change in the nature of the membership generates a chamber characterised by the politics of justification, rather than the politics of assertion that characterises the House of Commons (Norton 2016b, p. 129). Ministers have to engage with members. 
The procedures of the self-regulating chamber - not least the fact that there is no use of programme motions to timetable bills and that all amendments that are submitted are considered - facilitate the House in fulfilling its core, though not only, function of legislative scrutiny. The House may affect the outcome of legislation through defeats in the division lobbies, but its most pervasive influence is through persuading government to introduce amendments of its own in response to arguments advanced by members.

Meg Russell's study of twelve government bills in the period from 2005 to 2012 found that a majority of substantive government amendments (55 per cent) could be traced to amendments moved earlier by peers, with others attributable to reports from committees or pressure from MPs (Russell 2013, p. 173). The proportion is significant, but it is some of the individual changes achieved to bills that can be the most important aspect of the impact of the House of Lords. The House makes a difference to legislation, both in quantitative and qualitative terms.

The House has also followed the Commons in becoming more specialised through the use of committees and doing so in a way that complements committees in the Commons. In terms of investigate select committees, it has opted for committees that address cross-cutting issues and also committees that focus on secondary legislation. Among the former, the Constitution Committee has proved especially significant, acting as a constitutional watchdog (LeSeuer and Simson Caird 2013, p. 281). On the latter, the Delegated Powers and Regulatory Reform Committee examines the input side - the inclusion of order-making powers in a Bill - and the Secondary Legislation 
Scrutiny Committee examines the output side, looking at statutory instruments produced by government.

We also see collaboration between the chambers, with the Joint Committee on Human Rights, which has helped raise the profile of human rights in both Houses (Hunt, Hooper and Yowell, 2012), and occasional joint committees to engage in prelegislative scrutiny, complementing the work of pre-legislative scrutiny by Commons select committees. However, we can see the Lords coming into its own in respect of post-legislative scrutiny. Each session now, the House appoints an ad hoc committee to examine an Act or Acts covering particular fields. In the Parliament of 2010-15, committees were appointed to consider adoption (Select Committee on Adoption Legislation 2013a, 2013b), inquiries (Select Committee on the Inquiries Act 2005, 2014) mental health (Select Committee on the Mental Capacity Act 2005, 2014), and extradition (Select Committee on Extradition Law, 2015a, 2015b). In addition, the Delegated Powers and Regulatory Reform Committee in 2015 reviewed the Legislative and Regulatory Reform Act 2006. In the present Parliament returned in 2015, committees have examined the disability provisions of the Equality Act 2010 and the Licensing Act 2003.

As Meg Russell, Daniel Gover and Kristina Wolter (2016, pp. 286-308) have shown, in their article entitled 'Does the Executive Dominate the Westminster Legislative Process? Six Reasons for Doubt', parliamentarians do make a difference. Parliament has always been important in institutional terms (Norton 2013, pp. 6-7), but it is far more significant in pluralist terms than critics realise. Yes, there is still some way to go. There remain major problems, not least - as Daniel Greenberg (2016) has argued 
- from the growth in the volume of legislation. Secondary legislation is a particular problem in terms of volume - that is, the number of pages rather than the number of statutory instruments - and its complexity and scope. Nonetheless, what has been achieved in recent decades is remarkable.

Each of the changes outlined above is significant. Taken together, they represent a major transformation of Parliament from what existed for most of the late $19^{\text {th }}$ and for most of the $20^{\text {th }}$ Century. We are in danger of not appreciating just how significant the change has been.

\section{The Worst of Times}

Let us now look at the other side. In its relationship with the public, Parliament is under challenge and in a way it has not been for more than a century. It is confronted by several challenges and by a collective lack of confidence in facing those challenges. My argument is that it needs to confront these challenges and to do so robustly.

In many respects, as a representative body, Parliament matters now more than ever before. At times of uncertainty, legislatures become even more, not less, important as the voice of the people. The expressive function of Parliament becomes a major contributor to political stability. People need to feel that they are being heard and their views pursued. 
MPs spend a great deal of time dealing with constituency correspondence and spending time in their constituencies (Rosenblatt 2006, Korris 2011). People can, and do, on an increasing scale, make contact with their local MP (Norton 2012b, pp. 4078). Contact more often than not enhances a positive view of the MP. Parliament is more transparent than ever before. People can watch proceedings on television, not least the dedicated BBC Parliament channel, or the Internet (Democracy Live). They can watch now in real time. Both Houses, as detailed above, have become stronger in scrutinising government and calling it to account.

Why, then, does this not feed through to a positive perception of Parliament? Parliament is neither loved nor respected. The Hansard Society Audit of Political Engagement does not make for encouraging reading. The percentage of respondents in the latest audit who agree that 'Parliament is essential to our democracy' has increased from 61 per cent to 73 per cent (Hansard Society 2016, p. 24). That means, though, that there is still more than a quarter who have not agreed to the statement, and only 32 per cent of those questioned are satisfied with how Parliament does its job (Hansard Society 2016, p. 29). Distinguishing the institution from its members, only 29 per cent are satisfied with how MPs generally do their job.

These figures give ground for worry. Some may say that nonetheless they do not prove there is a crisis. If one compares trust in Parliament in the UK with trust in legislatures in other European nations, then we are not an outlier. Trust in the national Parliament in the UK is above the EU average, but still lagging well behind Scandinavian legislatures and several Western European legislatures (European Commission, 2015, p. T 54). We are only just above the average and the average is 
not encouraging: almost two-thirds of citizens tend not to trust their national parliament. The trend over the past decade has been a downward one (Eurobarometer data, 2004 to 2014). Only one-third of those surveyed in the UK 'tend to trust' Parliament. Both Houses are working hard, extremely hard, challenging the executive more effectively than at any point in recent history, but this nonetheless is not really seeping through to the citizen in terms of trust. Why not? What is the problem?

The answer is not to be found so much in terms of result-based performance, but more what Green has characterised as the actor-based perspective (Green 2013, p. 418). This was essentially my opening point in that students of politics have focused on the former and not on how politicians behave, or are seen or believed to behave, by the public. My contention is that it is not just a case of how politicians are seen, but that there is an increasing unwillingness to look at what they are doing.

There are three pressures external to Parliament. The first is popular cynicism. People have long taken a critical attitude to politicians as such, but for much of the $20^{\text {th }}$ Century there was a deferential attitude towards public figures. That was eroded by a more questioning media, led by reporters such as Robin Day, and by the growth of satirical programmes such as 'That Was the Week That Was'. As the ESRCfunded project on popular understandings of politics in Britain from 1937 to 2015 observed, 'Images of the good politician have changed and become more difficult for politicians to achieve' (ESRC/University of Southampton, 2016, p. 4). Expectations have become more demanding as the capacity to meet them has declined. 
That has been compounded by the second development, which has reinforced the cynical tendency, but is a development independent of it. We have seen a less interested, and less informed, media. This is not the product of the cynicism, but of commercial forces. Newspapers do not have the resources to cover Parliament now in detail are and aware that stories about Parliament do not boost circulation, unless related to individual or institutional scandal, such as an expenses' scandal. Although the Palace of Westminster is now more open to the media than it has ever been in its history, the incentive for the press particularly to be there is diminishing. Insofar as it is covered, there are not the resources to cover it on an informed basis. Even the BBC now variously exhibits a lack of basic knowledge about the institution. There are individual exceptions, not least BBC Parliament and its estimable reporter Mark D’Arcy, but they are precisely that - exceptions - and the fact that BBC Parliament is essentially run on a shoestring budget conveys the priority accorded to Westminster by the media.

The media, then, have no incentive to cover Parliament in depth and when they do are prone to reflect the cynical attitude towards politicians which is variously reinforced by the occasional scandal. In this respect, the United Kingdom is not unique. One finds the same attitude elsewhere, not least in the United States, where there is the perception that the country has, in Stern's words, 'the best Congress that money can buy' (Stern 1988), but it does nothing to enhance knowledge and appreciation of the nation's legislature.

The challenge to the print media has come through the emergence of new technology and the prevalence of the Internet. This is the third change and it has also created a 
separate problem for Parliament. There is a positive side, in that Parliament can seek to reach people directly through the Internet (Norton 2013, pp. 269-72) - it has invested significantly in the Parliament website - but it also has a pervasive negative effect. The technology has facilitated a more distracted electorate. In post-war years, political parties were able to attract interest and fulfil important social as well as political roles. They helped integrate people into society. The Young Conservative organisation was often portrayed as a marriage bureau. Now, we have a more specialised society and the Internet has produced a greater immediacy to what goes on. The iPhone or the Smartphone is the constant companions of possibly most citizens. People use them for instant contact with family and friends and, indeed, strangers and to find out what is happening in a myriad of situations. There is an immediacy to what people wish to extract. News of what is happening in Parliament is not normally to the fore.

Citizens, in short, have interests other than politics and the technology facilitates pursuit of those interests. Citizens are not necessarily alienated by politics, but distracted by other interests and willing to let politicians get on with it. Some people are interested in public policy, but that interest is not a central part of their activity. There has been the emergence of what has been termed e-expressives, who do follow and comment on politics, but who do not engage in political activity beyond the Internet (Cantijoch, 2014, pp. 69-72). People often have views on public issues, but little incentive to do anything about them.

The open nature of the Internet has also enabled anybody with a view to publish it, with no quality control. As Ian Martin wrote in May 2016 in his last newsletter as 
editor of CapX: 'The concern is that people are encouraged to live in an anti-social media echo-chamber, in which they only hear views and conspiracy theories which confirm their prejudices’ (Martin 2016). Problems that we have traditionally associated with the press are writ large in terms of the Internet.

These developments come together. It is easy to take a cynical view, because it is both cheap and entails no serious research or reflection.

However, Parliament itself is part of the problem, both in terms of behaviour and attitude. There are two particular dimensions to this.

First, the very work of both Houses has an opportunity cost. Challenging the executive is necessary, but it is time consuming and takes place within a confined environment. Constituency work is more and more time consuming - impinging negatively on the collective work of Parliament - yet constitutes contact with a small minority of the electorate; there are lots of letters, and now, on an even more extensive scale, e-mails, but many are from the same people. Being, in the eyes of some, glorified social workers constitutes work that could be undertaken by other agencies and is at the expense of engaging with people on a wider scale. Pursuing the interests of individual constituents is not the same as pursuing constituency interests (Norton and Wood 1993).

Second, and this is the point I wish to stress, there is a collective lack of confidence. This has got worse over time. It was apparent in the 1990s in the wake of the 'cash for questions' scandal and became pronounced in the expenses’ scandal of 2009 (see 
Winnett and Rayner 2009, Van Heerde-Hudson, 2014). Gordon Brown called it 'the biggest parliamentary scandal for two centuries’ (Winnett and Rayner 2009, p. 349). A survey of MPs who left the House in 2015, commissioned by the Administration Committee of the House of Commons, demonstrated how they perceived the public response. As the report noted, 'All interviewees acknowledged that the public perception of MPs had been significantly and negatively affected by the expenses scandal that broke in 2009'(Tinkler and Mehta 2016, p 14). One felt that the impact on the public lack of trust in politicians was ‘a blow that I don't think we will recover from in a lifetime’ (Tinkler and Mehta 2016, p 14).

The principal problem of the expenses' scandal was not in terms of public perceptions. As Nicholas Allen and Sarah Birch have shown, levels of trust in politicians were not much dented by the scandal and soon returned to pre-expenses' scandal level (Allen and Birch, 2014, pp. 132-52). The problem was in terms of Members' self-confidence. Members were essentially shell-shocked by the revelations and coverage, day by day, accorded to them.

This is not to say that there is not a problem of public perception of MPs. There is, but it is longstanding and has got worse over time. MPs have, as Matthew Flinders has argued, become a demonised group in the United Kingdom (Flinders 2012, pp. 117). My point is that we need to recognise that there is a problem, but it is not one that has reached a new high as a result of the expenses' scandal. The lesson to be drawn from this is that a 'tin hats' mentality, hoping that the problem will go away, is not sufficient. The problem is more ingrained and requires more than a short-term response. 
In so far as there has been a reaction, it has been defensive. New mechanisms have been created, but nothing that is proactive. The creation of the Independent Parliamentary Standards Authority (IPSA) is the product of a rushed, and flawed, response and has done nothing notably to restore public trust. Both Houses, the House of Lords in particular, have done more to strengthen their disciplinary mechanisms, but again, though welcome and indeed necessary, they do not constitute a means of having a noticeable effect on public perceptions of Parliament.

I stress Parliament because that leads to my next point. Parliamentarians are part of the problem, but they are also a necessary part of the solution. They are a necessary part because of the unique nature of legislatures. There is the constitutional entity that is Parliament. That entity comprises, in addition to the Crown, a combination of two distinct units, the House of Commons and the House of Lords. Each House comprises a membership that is the sum of a large number of independent units. This sets Parliament apart from companies or any other corporate entity.

The relevance of this for our purposes is that there is no one individual who can claim to speak for Parliament. There is no equivalent of a company chair, someone who can speak for the institution, not least at times of crisis. There is no chief executive officer of Parliament and the chief executive officer of each House is not analogous to the CEO of a major corporation.

When there is a scandal, who can answer on behalf of the institution? When a crisis hits a company, there is usually the chairman and CEO available to act and to speak on behalf of the company (see Griffin 2014). They may well be trained ready for 
such an occasion. It is best practice among leading companies. They know the need, first, to recognise that there is a crisis, and, second, to respond once that realisation occurs.

In Parliament, there are leadership positions in each House, there is some co-operation between the Houses, and there are press officers. However, the fact that there are leadership positions may itself be a problem rather than part of the solution, involving the need for contact and co-ordination, which take time, and possibly creating conflict or tension. Press officers can act quickly if authorised, but they cannot be the authoritative voice of the institution. The media look to the head of the organisation to respond. There is no such head as far as the legislature is concerned.

There is a case for Parliament addressing this problem, or addressing the need for quick responses in particular situations, and to some extent contingency planning has taken place. Both Houses continue to invest in an Education Service and a new and imposing Education Centre. But none of this can address the problem I am identifying. If no one individual can speak for the institution of Parliament, then it becomes a matter for the members themselves. The reputation of Parliament can only be enhanced if the Members of each House adopt a proactive rather than a reactive stance. To return to the bunker analogy, it is important that the Members come out of the bunker, guns firing.

What is required is a restoration of political confidence and a means of giving effect to it. Citizenship education has been introduced in the national curriculum for schools as a way of ensuring that people know about Parliament and its role. But we need a 
similar exercise within Parliament itself. MPs and peers - especially MPs - need to stand back from their daily routine to appreciate the role of the very institution of which they are members. They need then to go on the offensive.

Members need to recognise that it cannot be left to others. That does not mean that those in leadership positions cannot take a role - they can and should - but my point is that this by itself is not sufficient. Members have to come out of the bunker. They have to have the political will to do so as well as the resources, not least time and a better command of the means of reaching electors. We cannot proceed on the basis that everything I have outlined about the two Houses provides the tools to persuade the public that members of each House deserve their confidence. People need to trust parliamentarians and that will come when parliamentarians have confidence in themselves and are prepared to act to demonstrate that they are worthy of trust. My view is that Members are worthy of public trust - MPs and peers are generally hardworking, conscientious and able individuals - but that is not how others see them.

The media and the public are prone to generalise from an $N$ of 1 . We need to be able to deal with the one, but we need also to go beyond that. It is not easy. Members tend to be too defensive - that is at the heart of the problem - and unwilling to make changes to tackle the problem.

It is crucial to recognise that some of the criticism of each House is not without merit, and address such things as the appointment process to the House of Lords, but there is a need, a glaring need, for MPs and peers to provide a lead. Some members have 
shown leadership - they have confidence and have mastered the means of engaging with electors - so it can be done. But they need to be the norm, not the exception.

Members cannot shuffle off responsibility. They need to accept, indeed to embrace, it and to promote vigorously the institution of which they are members. This can be justified in terms of rational action theory in that it is in Members' own interests to promote the body of which they are members and which sustains them. This does not detract from the adversarial debate that characterises the Commons. Members should be seen to be challenging and questioning, but they need also to recognise that they constitute the buckle between electors and government. They need to be more outward facing.

That challenge is even greater in the light of recent events. As I said in a debate in the House of Lords on the outcome of the June 2016 EU referendum, the campaign demonstrated Downs’ economic theory of democracy (Downs 1957), each side seeking to outbid the other, raising expectations that were not likely to be met, whichever side won:

This creates a problem of trust in our political system and indeed in our institutions. Government has responsibility for negotiating withdrawal, but Parliament has a crucial role of scrutiny and of linkage between government and people. We have to inform, but it is a two-way process. We have to try to ensure that the gap between expectations and what can be delivered is narrowed. (HL Deb. 6 July 2016, col. 2087) 
That is a fundamental challenge.

\section{Conclusion}

I conclude by summarising my points. First, parliamentarians need to adopt a more outward looking approach and address the relationship between members and the public, not simply at the reactive and micro level of constituency casework, but at the broader macro level, addressing how citizens see the behaviour of parliamentarians. Second, how the public views politicians has become more negative over time and is not the product of recent specific scandals, though these may have, in the short term, exacerbated public perceptions. Third, the views of the public derive from broader societal and technological changes and these create major problems for parliamentarians, both in attracting attention and in affecting how the public view them. Fourthly, insofar as parliamentarians can make a difference, it is not by ignoring the changes and hoping that over time negative public perceptions will dissipate. Parliamentarians cannot look to others to solve the problem of public perception for them. Parliamentary education and outreach can have some impact on citizenship education - a long-term solution - but in the immediate future it rests with parliamentarians to challenge and to engage. What is needed at a minimum is to meet public expectations in terms of conveying a sense of public service. There was some public recognition of that service in the wake of the murder in June 2016 of Jo Cox, the MP for Batley and Spen, but that awareness needs to be nurtured and embedded. Parliamentarians need to convey that they are listening and providing that Powellian link between people and government. 
Identifying what needs to be done is one thing, achieving it is another. As already argued, in crisis management, the first essential step is to realise that there is a crisis. What Parliament faces may not be a crisis, at least not on the scale faced by the US Congress, but it is a serious problem that needs to be faced. Unless it is faced, it may well become a crisis. My task in this article has been to establish the first but not the only step in what needs to be done. These need not be the worst of times. It is essential for MPs and peers to ensure that they are not.

\section{Acknowledgements}

This article is based on my Michael Ryle Memorial Lecture, delivered in Speaker's House, Westminster, on 19 July 2016. For insights into crisis management, I am especially grateful to Andrew Griffin.

\section{References}

Allen, N. and Birch, S. (2014), 'Tempests and Teacups: Politicians' Reputations in the Wake of the Expenses Scandal', in J. Van Heerde-Hudson (ed), The Political Costs of the 2009 British MPs’ Expenses Scandal, Basingstoke, Palgrave Macmillan, 2014.

Beer, S. H. (1969), Modern British Politics, revised edn., London, Faber.

Cantijoch, M. (2014), 'Will joke, won't vote: the internet and political engagement', in P.Cowley and R. Ford (eds), Sex, Lies \& the Ballot Box, London, Biteback Publishing.

Cowley, P. (2002), Revolts and Rebellions, London, Politico’s.

Cowley, P. (2005), The Rebels, London, Politico’s.

Cowley, P. (2015), 'The coalition and Parliament', in A. Seldon and M. Finn (eds), The Coalition Effect, 2010-2015, Cambridge, Cambridge University Press.

Cowley, P. and Norton, P. (1999), 'Rebels and Rebellions: Conservative MPs in the 1992 Parliament', The British Journal of Politics and International Relations, 1, 84-105.

Cowley, P. and Stuart, M. (2012), 'A Coalition with Two Wobbly Wings: Backbench Dissent in the House of Commons', Political Insight, 3, 8-11.

Cowley, P. and Stuart, M. (2014), 'In the Brown Stuff? Labour Backbench Dissent under Gordon Brown, 2007-2010’, Contemporary British History, 28, 1-23. 
Delegated Powers and Regulatory Reform Committee, House of Lords (2015), PostLegislative Assessment of the Legislative and Regulatory Reform Act 2006, 20 ${ }^{\text {th }}$ Report, Session 2014-15, HL Paper 132.

Downs, A. (1957), An Economic Theory of Democracy, New York, Harper.

Drewry, G. (1989), (ed) The New Select Committees, revised edn., Oxford, Clarendon Press.

ESRC/University of Southampton (2016), The rise of anti-politics in Britain, Southampton, University of Southampton.

European Commission (2015), Public Opinion in the European Union, Standard Eurobarometer 84, Autumn 2015, Brussels, European Commission.

Flinders, M. (2012), 'The demonisation of politicians: moral panics, folk devils and MPs' expenses’, Contemporary Politics, 18, pp. 1-17.

Green, J. E. (2013), ‘Analysing legislative performance: a plebeian perspective’, Democratization, 20, 417-37.

Greenberg, D. (2016), 'Dangerous Trends in Modern Legislation - and How to Reverse Them', Pointmaker, London, Centre for Legislative Studies.

Griffin, A. (2014), Crisis, Issues and Reputation Management, London, Kogan Page.

Hansard Society (2016), Audit of Political Engagement 13: The 2016 Report, London, The Hansard Society.

Hawes, D. (1993), Power on the Back Benches? The Growth of Select Committee Influence, Bristol, SAUS Publications.

Hunt, M., Hooper, H. and Yowell, P. (2012), Parliament and Human Rights: redressing the democratic deficit, Swindon, Arts and Humanities Research Council.

Hindmoor, A., Larkin, P. and Kennon, A. (2009), 'Assessing the Influence of Select Committees in the UK: The Education and Skills Committee, 1997-2005', The Journal of Legislative Studies, 15, 71-89.

Jorgerst, M. (1993), Reform in the House of Commons, Lexington KY, University Press of Kentucky.

Korris, M. (2011), A year in the life. From members of public to Members of Parliament, London, Hansard Society.

LeSeuer, A. and Simson Caird, J. (2013), 'The House of Lords Select Committee on the Constitution', in A. Horne, G. Drewry and D. Oliver (eds), Parliament and the Law, Oxford, Hart Publishing.

Martin, I. (2016), 'The collapse of the press and the rise of anti-social media puts democracy in peril', CapX, 27 May, http://capx.co/the-collapse-of-the-press-and-the-rise-of-anti-socialmedia-putsd-democracy-in-peril/

Natzler, D. and Hutton, M. (2005), 'Select Committees: Scrutiny à la Carte', in P. Giddings (ed), The Future for Parliament: Issues for a New Century, Basingstoke, Palgrave Macmillan. 
Norton, P. (1975), Dissension in the House of Commons 1945-74, London, Macmillan.

Norton, P. (1978), Conservative Dissidents, London, Temple Smith.

Norton, P. (1980), Dissension in the House of Commons 1974-1979, Oxford, Clarendon Press.

Norton, P. (1985), ‘The House of Commons: Behavioural Changes', in P. Norton (ed), Parliament in the 1980s, Oxford, Basil Blackwell.

Norton, P. (2003), 'Cohesion Without Discipline: Party Voting in the House of Lords', The Journal of Legislative Studies, 9, pp. 57-72.

Norton, P. (2012a), 'Coalition Cohesion', in T. Heppell and D. Seawright (eds), Cameron and the Conservatives, Basingstoke, Palgrave Macmillan.

Norton, P. (2012b), 'Parliament and Citizens in the United Kingdom', The Journal of Legislative Studies, 18, 403-18.

Norton, P. (2013), Parliament in British Politics, $2^{\text {nd }}$ edn., Basingstoke, Palgrave Macmillan.

Norton, P. (2015), 'Parliament: A New Assertiveness?' in J. Jowell, D. Oliver, and C.

O’Cinneide (eds), The Changing Constitution, $8^{\text {th }}$ edn., Oxford: Oxford University Press.

Norton, P. (2016a), 'The Fixed-term Parliaments Act and Votes of Confidence', Parliamentary Affairs, 69, 3-18.

Norton, P. (2016b), Legislative Scrutiny in the House of Lords' in A. Horne and A. Le Sueur (eds), Parliament: Legislation and Accountability, Oxford, Hart Publishing.

Norton, P. and Wood, D. M. (1993), Back from Westminster, Lexington KY: University Press of Kentucky.

Rosenblatt. G. (2006), A year in the life, London, Hansard Society.

Russell, M. (2011), '”Never Allow a Crisis to Go to Waste”: The Wright Committee Reforms to Strengthen the House of Commons', Parliamentary Affairs, 64, 612-33.

Russell, M. (2013), The Contemporary House of Lords, Oxford, Oxford University Press.

Russell, M. Gover, D. and Kristina Wolter, K, (2016), 'Does the Executive Dominate the Westminster Legislative Process? Six Reasons for Doubt', Parliamentary Affairs, 69, pp. 286-308.

Saalfeld, T. (2000), Evidence, Commission to Strengthen Parliament, Strengthening Parliament, London, The Conservative Party.

Select Committee on Adoption Legislation, House of Lords (2013a), Adoption: PreLegislative Scrutiny, $1^{\text {st }}$ Report, Session 2012-13, HL Paper 94.

Select Committee on Adoption Legislation, House of Lords (2013b), Adoption: PostLegislative Scrutiny, ${ }^{\text {nd }}$ Report, Session 2012-13, HL Paper 127. 
Select Committee on Extradition Law, House of Lords (2015a), The European Arrest Warrant Opt-in, $1^{\text {st }}$ Report, Session 2014-15, HL Paper 63.

Select Committee on Extradition Law, House of Lords (2015b), Extradition: UK law and practice, $2^{\text {nd }}$ Report, Session 2014-15, HL Paper 136.

Select Committee on the Inquiries Act 2005, House of Lords (2014), The Inquiries Act 2005: post-legislative scrutiny, Session 2013-14, HL Paper 143.

Select Committee on the Mental Capacity Act 2005, House of Lords (2014), Mental Capacity Act 2005: post-legislative scrutiny, Session 2013-14, HL Paper 139.

Stern, P. M. (1988), The Best Congress Money Can Buy, New York, Random House.

Straw, J. (2012), Last Man Standing, London, Macmillan.

Thompson, L. (2015), Making British Law, Basingstoke, Palgrave Macmillan.

Thompson, L. (2016), 'Debunking the Myths of Bill Committees in the British House of Commons', Politics, 36, 36-48.

Tinkler, J. and Mehta, N.(2016), Report to the House of Commons Administration Committee on the findings of the interview study with Members on leaving Parliament, London, House of Commons Administration Committee.

Van Heerde-Hudson, J. (2014), (ed) The Political Costs of the 2009 British MPs' Expenses Scandal, Basingstoke, Palgrave Macmillan.

Winnett, R. and G. Rayner, G. (2009), No Expenses Spared, London, Bantam Press. 